\title{
Pengaruh Store Atmosphere Terhadap Keputusan Pembelian Di Gramedia Manado
}

\author{
Desilsan Tansala \\ Tinneke M. Tumbel \\ Olivia F. C. Walangitan
}

Jurusan Ilmu administrasi, Program Studi Administrasi Bisnis

Fakultas Ilmu Sosial dan Politik, Universitas Sam Ratulangi

desilsantansala9@gmail.com

\begin{abstract}
Store atmosphere is an atmosphere that refers to the physical characteristics of exterior buildings and interior spaces, which shape the store image and bring in customers. This study aims to determine the effect of store atmosphere on consumer purchasing decisions at Gramedia Manado Sam Ratulangi. The problem in this study is the problem of parking where when going to Gramedia is less comfortable, jammed and narrow, there is a lack of sanitary hygiene, and sometimes changes in shelves and location marks make consumers confused. The type of research used in this study is descriptive quantitative research, using questionnaires and using a Likert scale. The population is all Gramedia Sam Ratulangi Manado consumers whose population size is unknown. Samples taken amounted to 80 respondents using probability sampling method that is by simple random sampling technique. The statistical analysis used in this study is a simple regression analysis using SPSS 25 for windows. The results of this study indicate that store atmosphere has a positive and significant effect on purchasing decisions. The amount of store atmosphere influence on purchasing decisions is $54.7 \%$ and $45.3 \%$ is influenced by other factors not examined in this study such as product quality, price, promotion and store associate factors that were not examined in this study.
\end{abstract}

Keywords : store atmosphere, purchasing decisions

\section{Pendahuluan}

Kegiatan usaha bertujuan untuk mempertahankan keberadaan suatu perusahaan di tengah persaingan agar mendapatkan keuntungan, menciptakan store atmosphere yang menyenangkan sehingga terjadi keputusan pembelian.

Strategi store atmosphere mempunyai dampak yang sangat besar dalam mempengaruhi suasana hati konsumen, yang pada akhirnya diharapkan dapat menumbuhkan minat dalam membeli.
Desain toko yang tepat dapat mengubah orang dari yang sekedar melihat-lihat mempunyai minat ingin membeli.

Menciptakan atmosphere yang menyenangkan pada saat di dalam toko, akan memberikan nilai tambah terhadap produk yang dijual dan juga menjadi strategi alternatif yang tepat dalam menghadapi persaingan. Selain itu, store atmosphere juga menentukan citra toko itu sendiri. Sebuah toko yang memiliki citra baik dapat menjamin kelangsungan hidup 
suatu perusahaan agar dapat bertahan terhadap persaingan dalam membentuk pelanggan yang loyal. Keputusan pembelian konsumen dipengaruhi oleh salah satu faktor yaitu situasi konsumen itu sendiri. Situasi konsumen ditandai dengan peristiwa yang relatif jangka pendek dan terdiri dari faktor lingkungan sementara yang membentuk konteks dalam suatu kegiatan konsumen, yang terjadi pada waktu dan tempat tertentu.

Gramedia merupakan perusahaan ritel yang menerapkan konsep store atmosphere dalam menjalankan usahanya. Gramedia merupakan toko buku terlengkap dan terbesar yang tempatnya di Jl. Sam Ratulangi No. 45, Wenang Selatan, Wenang, Kota Manado mendapat perhatian yang tinggi dari pemerintah dan pola hidup masyarakat Indonesia yang mulai berubah, mendorong bisnis ini tumbuh pesat. Dalam meraih minat beli konsumen tidaklah mudah karena di Manado sendiri memiliki beberapa toko buku yang menjadi pesaing seperti toko buku Kharisma, toko buku Kristen Imanuel, toko buku BPK Gunung Mulia dan lain-lain yang juga menyediakan buku dan peralatan sekolah lainnya seperti yang dijual pada Gramedia. Berdasarkan hasil observasi awal oleh penulis pada toko buku Gramedia terlihat bahwa parkiran saat akan masuk ke Gramedia kurang nyaman dimana situasi masuk portal parkiran macet karena parkiran yang kurang luas. Kemudian juga ada perubahan pengaturan rak barang dan juga tanda petunjuk lokasi buku terdapat pembaharuan tempat yang membuat konsumen kebingungan untuk mencari buku yang mereka inginkan Pada saat observasi awal juga kadang peneliti pernah temukan kurangnya kebersihan pada sarana sanitasi (toilet) yang dapat menghambat konsumen yang tiba-tiba ingin BAK ataupun $\mathrm{BAB}$, sehingga apabila perusahaan tidak dapat menanggulangi masalah ini maka perusahaan akan kehilangan banyak konsumen yang dapat menurunkan omset perusahaan dan efeknya perusahaan akan mengalami kerugian.

\section{Manajemen Pemasaran}

\section{American Marketing Association} (AMA) mendefinisikan bahwa manajemen pemasaran sebagai berikut: "Manajemen pemasaran sebagai seni dan ilmu memilih pasar sasaran dan mendapatkan, menjaga, dan menumbuhkan pelanggan dengan menciptakan, menyerahkan, dan mengomunikasikan nilai pelanggan yang unggul” (Kotler dalam selang 2013). Menurut Armstrong dan kotler (2012), manajemen pemasaran adalah serangkaian proses yang dilakukan oleh perusahaan untuk menciptakan suatu nilai bagi para pelanggan dan membangun hubungan yang kuat dengan mereka agar tercipta suatu nilai dari para pelanggan tersebut.

\section{Store Atmosphere}

Store atmosphere merupakan suasana yang mengacu pada karakteristik fisik 
bangunan eksterior serta ruangan interior, yang membentuk citra dan mendatangkan pelanggan. Menurut Katarika (2017), store atmosphere merupakan suatu faktor penting bagi pusat perbelanjaan untuk dapat membuat konsumen merasa tertarik untuk datang berkunjung dan nyaman dalam berbelanja. Menurut Paila (2018), banyak orang membentuk kesan toko sebelum memasuki atau hanya setelah memasuki toko tersebut. Konsumen bisa menilai sebuah toko sebelum memeriksa barang dagangan dan harga pada toko tersebut. Suasana toko dapat mempengaruhi kenikmatan orang dalam berbelanja dan menghabiskan waktu pada toko itu.

\section{Elemen-elemen store atmosphere}

Menurut Berman \& Evans (2010: 509) dapat dibagi menjadi empat elemen utama, yaitu:

1. Exterior (Bagian Luar Toko), meliputi papan nama toko, pintu masuk toko, tampilan pajangan, toko dan area sekitarnya dan fasilitas tempat parkir.

2. General Interior (Interior Umum), meliputi jenis lantai, warna dan pencahayaan, aroma dan musik, aroma toko, tekstur dinding, suhu udara, lebar jarak, kamar pas, alat transportasi antar lantai dan kebersihan toko.

3. Store Layout (tata letak toko), Rencana untuk menentukan lokasi dan penyusunan dari peralatan toko, barang dagangan, gang-gang dalam toko serta fasilitas toko nantinya akan menjadi salah satu faktor yang dapat menarik konsumen.

4. Interior (Point-of-Purchase) Display, Setiap point-of-purchase displays menyediakan pembeli dengan informasi, menambahkan untuk atmosfer toko, dan melayani peran promosi besar.

\section{Keputusan Pembelian}

$\begin{array}{cccc}\text { Keputusan } & \text { pembelian } & \text { adalah } \\ \text { perilaku seorang } & \text { konsumen } & \text { dalam }\end{array}$ melakukan pemilihan suatu produk yang akan dibeli yaitu proses mulai dari melihat hingga akhirnya mengambil keputusan terhadap produk tersebut. Menurut Kotler (2016: 195), bahwa keputusan pembelian dikelompokan menjadi:

1. Pengenalan Masalah

Proses pembelian dimulai ketika pembeli mengenali masalah atau kebutuhan. Kebutuhan tersebut dicetuskan oleh rangsangan internal atau eksternal. Rangsangan internal merupakan salah satu kebutuhan umum seseorang lapar atau haus, sedangkan oleh rangsangan eksternal merupakan rangsangan dari lingkungan seperti seseorang bisa mengagumi mobil baru tetangganya dan memikirkan kemungkinan melakukan suatu pembelian.

2. Pencarian Informasi

Konsumen yang terangsang kebutuhannya akan mencari informasi yang lebih banyak. Sehingga yang menjadi perhatian utama dari pemasar 
adalah sumber-sumber informasi yang menjadi acuan konsumen dan pengaruh tiap sumber tersebut terhadap keputusan pembelian. Sumber informasi digolongkan kedalam empat kelompok, yaitu:

a) Sumber pribadi: keluarga, teman, tetangga, kenalan.

b) Sumber komersial: iklan, wiraniaga, penyalur, kemasan, pajangan di toko.

c) Sumber public: media massa, organisasi penentu peringatan konsumen.

d) Sumber pengalaman: penanganan, pengkajian dan pemakaian produk

3. Evaluasi Alternatif Tahap dimana seseorang mengumpulkan informasi yang didapatkan dan mengevaluasi alternatif-alternatif suatu produk yang sesuai dengan kebutuhan.

4. Keputusan Pembelian

Dalam pembelian, konsumen bisa mengambil lima sub-keputusan: merek (merek A), dealer (dealer 2), keantitas/ kuantitas(sebuah computer), waktu (akhir pekan) dan metode pembayaran (kartu kredit). Dalam suatu kasus pembelian misalnya dalam membeli gula konsumen tidak banyak berpikir mengenai metode pembayaran maupun pemasoknya.

5. Perilaku Pasca Pembelian

Tahap dimana konsumen telah melakukan pembelian dan mengukur kepuasan mereka terhadap produk tersebut. Jika poduk yang mereka beli tidak sesuai dengan harapan maka konsumen akan merasa tidak puas, jika sesuai harapan maka mereka akan sangat puas, jika melebihi dari yang mereka harapkan maka diharapkan dapat melakukan pembelian ulang. Komunikasi pemasaran harus memasok keyakinan dan evaluasi yang mengukuhkan pilihan konsumen dan membantu konsumen merasa nyaman dengan merek.

\section{Metode Penelitian}

Dalam penelitian yang dilakukan pada Gramedia Jl. Sam Ratulangi No. 45, Wenang Selatan, Kota Manado, penulis menggunakan metode penelitian kuantitatif deskriptif. Populasi dalam penelitian ini adalah pengunjung / konsumen di toko buku Gramedia Manado yang tidak diketahui jumlah populasi pastinya. Sampelnya berjumlah 80 responden karena banyaknya keterbatasan dalam melakukan penelitian. Teknik yang digunakan dalam menentukan sampel yaitu berdasarkan Roscoe dalam Sugiyono (2017: 155) menyarankan untuk ukuran sampel untuk penelitian yang layak dalam penelitian adalah antara 30 sampai dengan 500" . Teknik pegumpulan data yaitu kuisioner yang dinilai menggunakan skala Liker, dan model analisis yang digunakan yaitu analisis regresi sederhana. 


\section{Hasil dan Pembahasan}

Hasil yang didapatkan sesuai analisis uji validitas dengan menggunakan SPSS 25 for windows menyatakan bawha semua pernyataan pada kuisioner dinyatakan valid karena diketahui bawha Store Atmosphere (X) dan keputusan pembelian (Y), semua item pernyataan memiliki nilai signifikasi lebih kecil dari 0,05 yaitu 0,000 Berdasarkan hasil distribusi menunjukan keseluruhan jawaban responden tentang Store atmosphere yang menjadi variabel bebas ( independent variabel $\mathrm{X}$ ) didapatkan hasil rata-rata indikator eksterior yang menjawab setuju sebanyak $49,35 \%$, sangat setuju sebanyak 21,9\%, general interior yang menjawab setuju sebanyak 55\%, sangat setuju sebanyak $32,65 \%$, store layout yang menjawab setuju sebanyak 50,05\%, sangat setuju sebanyak $24,35 \%$, interior display yang menjawab setuju 49,4\% dan sangat setuju sebanyak 17,5\%. Kemudian berdasarkan distribusi pernyataan tentang keputusan pembelian variabel teikat ( independent variabel Y) di dapatkan rata-rata jawaban tentang merek yang menjawab sangat setuju sebanyak $20 \%$, setuju sebanyak 53,75\%, kuantitas/jumlah jawaban sangat setuju sebanyak $23,15 \%$, setuju sebanyak $51,9 \%$, waktu pembelian menjawab sangat setuju sebanyak $18,75 \%$, setuju sebanyak $46,9 \%$ dan metode pembayaran yang menjawab sangat setuju sebanyak $14,4 \%$ dan setuju $36,25 \%$.
Berdasarkan hasil penelitian yang telah dilakukan menggunakan analisis regresi sederhana, diketahui bahwa store atmosphere berpengaruh positif terhadap keputusan pembelian konsumen dihitung dengan koefisien korelasi yaitu 0,740. Hal ini menunjukan bahwa ada pengaruh yang kuat antara store atmosphere dengan keputusan pembelian, arah hubungannya positif (tidak ada tanda negatif pada angka 0,740), nilai signifikansi sebesar 0,000 jika dibandingkan dengan nilai $\alpha=0,05(0,000$ $<0,05)$ atau $(0,05>0,000)$, maka dapat dijelaskan bahwa hipotesis dalam penelitian ini Ha diteima dan Ho ditolak yang artinya variabel store atmosphere berpengaruh terhadap keputusan pembelian konsumen di Gramedia manado. Selain itu hasil uji koefisien determinasi, hasil analisis menunjukkan bahwa nilai dari koefisien determinasi (Rsquere) sebesar 0,547 atau $54,7 \%$, artinya variabel store atmosphere memberikan pengaruh sebesar $54,7 \%$ terhadap keputusan pembelian konsumen di toko buku Gramedia Samratulangi Manado, sedangkan 45,3\% yang mempengaruhi keputusan pembelian konsumen adalah faktor di luar store atmosphere seperti faktor kualitas produk, harga, promosi dan store associate yang tidak diteliti dalam penelitian ini.

Hasil penelitian ini mendukung penelitian yang pernah dilakukan oleh Fahima Achmad, dkk. (2015) dengan judul "Pengaruh Store Atmosphere terhadap 
Keputusan Pembelian konsumen pada pengunjung di Madam Wang Secret Garden Cafe Malang”, yang menyimpulkan bahwa store atmosphere yang terdiri dari komunikasi visual, pencahayaan, warna, musik dan aroma berpengaruh positif terhadap keputusan pembelian konsumen di Madam Wang Secret Garden Cafe Malang. Atmosphere berhubungan dengan bagaimana para manajer dapat memanipulasi desain bangunan, ruang interior, tata ruang lorong-lorong, tekstur karpet dan dinding, aroma, warna, bentuk, dan suara yang dialami para konsumen yang semuanya bertujuan untuk memengaruhi konsumen dalam keputusan pembeliannya (Mowen \& Minor, 2002: 139).

Menurut Utami (2005: 138) dalam Melisa (2012: 4), atmosphere mampu mempengaruhi kenikmatan konsumen dalam berbelanja, dan mampu menciptakan pengalaman berbelanja yang nyaman dan menyenangkan. Konsumen akan menghabiskan waktu dan uang yang banyak dikarenakan oleh atmosphere belanja yang baik. Oleh karena itu, dapat dikatakan bahwa semakin baik pengelolaan store atmosphere maka semakin baik pula persepsi konsumen atas store atmosphere tersebut dan semakin besar pula dorongan konsumen untuk melakukan pembelian pada toko tersebut.

\section{Kesimpulan}

Berdasarkan hasil penelitian dan pembahasan maka dapat diambil kesimpulan sebagai berikut :

1. Store atmosphere memberi pengaruh positif dan kuat terhadap keputusan pembelian konsumen di Gramedia Manado.

2. Store atmosphere memberikan pengaruh sebesar $54,7 \%$ terhadap keputusan pembelian konsumen di toko buku Gramedia Samratulangi Manado sedangkan $45,3 \%$ yang mempengaruhi keputusan pembelian konsumen adalah faktor di luar store atmosphere seperti faktor kualitas produk, harga, promosi dan store associate yang tidak diteliti dalam penelitian ini.

\section{Saran}

Berdasarkan hasil penelitian, pembahasan, dan kesimpulan yang diperoleh, maka saran yang dapat diberikan sebagai berikut:

Variabel store atmosphere memberikan pengaruh terhadap keputusan pembelian konsumen Gramedia Manado. Berdasarkan penilaian responden dalam penelitian ini, upaya yang sebaiknya dilakukan oleh Gramedia Manado yaitu lebih memperhatikan pengelolaan pada store atmosphere di Gramedia Manado terutama pada penataan jarak antar rak, pemberian tanda petunjuk, untuk sanitasi yang mudah dijangkau dan penataan parkiran yang lebih baik. Gramedia 
Manado juga perlu memperhatikan dan menindaklanjuti keluhan-keluhan konsumen yang menyangkut store atmosphere yang ada di Gramedia Manado, sehingga konsumen dapat merasakan kenyamanan saat melakukan pembelian dan dapat mendorong keputusan pembelian mereka.

Peneliti selanjutnya dapat mengembangkan penelitian ini dengan melakukan penelitian pada faktor-faktor lain seperti faktor kualitas produk, harga, promosi dan store associate yang tidak diteliti dalam penelitian ini yang dapat memengaruhi keputusan pembelian konsumen. Besarnya faktor store atmosphere hanya merupakan salah satu faktor yang mempengaruhi keputusan pembelian konsumen sebagaimana yang diteliti dalam penelitian ini. Peneliti selanjutnya dapat menganalisis faktor-faktor lain yang memberikan kontribusi terhadap keputusan pembelian konsumen pada department store, supermarket, maupun jenis ritel yang lainnya.

\section{Daftar Pustaka}

Berman, Barry dan Joel R. E. 2010. Retailing Management, 11th edition, Boston: Pearson.

Fahimah, Fauzi A dan Hidayat K. 2015. Pengaruh store atmosphere (suasana toko) terhadap keputusan pembelian di Madam Secret Cafe Malang. Jurnal Administrasi Bisnis 28 (2)

Katarika D. Merinda dan syahputra. 2017. Pengaruh store atmosphere terhadap keputusan pembelian pada coffe shop Bandung. Jurnal Ecodemica 1 (2).

Kotler, Philip \& Gary Armstrong. (2012). Principle of Marketing, 14th ed.Global Edition England : Pearson Education.

Kotler, Philip and Kevin Lane Keller, (2016): Marketing Management, 15th Edition New Jersey: Pearson Pretice Hall, Inc

Melisa, Yuda. (2012). "Pengaruh Bauran Pemasaran Ritel terhadap Keputusan Pembelian Ulang Konsumen Mega Prima Swalayan Payakumbuh". Jurnal Manajemen. Universitas Negeri Padang, 1 (1).

Mowen, John C dan Michael Minor. 2002. Perilaku Konsumen. Edisi 5. Jakarta ; Erlangga.

Paila J. A., Kalangi J.A.F., dan Rogahang J. J. 2018. Pengaruh suasana toko terhadap minat beli konsumen pada UD. Sinar Anugerah Pratama Manado. Jurnal Administrasi Bisnis 6 (1).

Selang Christian A.D. 2013. Bauran Pemasaran (Marketing Mix) Pengaruhnya Terhadap Loyalitas Konsumen Pada Fresh Mart Bahu Mall Manado. Jurnal EMBA 1, (3): 71-80. 